\title{
Why is Aedes aegypti Linnaeus so Successful as a Species?
}

\author{
FD Carvalho, LA Moreira
}

Mosquitos Vetores: Endossimbiontes e Interação Patógeno-Vetor, Centro de Pesquisas René Rachou / Fundação Oswaldo Cruz (CPqRR /

Fiocruz), Belo Horizonte, Minas Gerais, Brazil

\section{Keywords}

Mosquitoes, Wolbachia, transgenics, control, arboviruses

\section{Correspondence \\ FD Carvalho, Mosquitos Vetores: Endossimbiontes e Interação Patógeno- Vetor, Centro de Pesquisas René Rachou / Fundação Oswaldo Cruz (CPqRR / Fiocruz), Belo Horizonte, Minas Gerais, Brazil; fabiano.carvalho@cpqrr.fiocruz.br}

Edited by Adeney de Freitas Bueno Embrapa Soja

Received 12 December 2016 and accepted 22 March 2017

(C) Sociedade Entomológica do Brasil 2017

\begin{abstract}
Diseases transmitted by mosquitoes impose enormous burden towards human morbidity and mortality. Over the last three decades, Brazil has suffered from severe Dengue epidemics. In September 2014, this situation is further complicated by the introduction of two other viruses, Zika and Chikungunya, placing Brazil in a triple epidemic. In this article, we discuss the biology of Aedes aegypti Linnaeus, and the principal initiatives currently used to control mosquito populations and the diseases they transmit. Aedes aegypti has broad global distribution and is involved in the transmission of various arboviral diseases such as Dengue, Zika, and Chikungunya. Several factors contribute to the success of the species, particularly behavioral plasticity, rapid development, desiccationresistant eggs, resistance to the principle insecticide classes currently available on the market, preference for the urban environment, and proximity to humans. Vector control programs are the best way to reduce the burden of mosquito-borne diseases. Chemical control is most commonly used in recent times, and unfortunately, the results have not been satisfactory but instead, there is increased vector dispersal and, subsequently, the spread of disease epidemics. Investigations of alternative control methods such as release of Wolbachia-infected mosquitoes for blocking vectorborne pathogens, release of transgenic mosquitoes carrying a lethal gene for offspring, and the use of insecticide-dispersing mosquitoes are under way in Brazil, and some have shown promising results. Special emphasis should be placed on integrated management of all available tactics, so as to maximize efforts towards mosquito control. Finally, we emphasize that continuous actions and community participation control initiatives are critically important for success.
\end{abstract}

\section{Introduction}

Diseases transmitted by mosquitoes impose enormous burden towards human morbidity and mortality. In the last three decades, Brazil has suffered severe Dengue epidemics caused by widespread circulation of the four viral serotypes. This situation in Brazil was further complicated in September 2014 by the introduction of Zika and Chikungunya, causing a triple epidemic. Further, neurological complications likely related to the Zika virus worsened public health threats. The
Ministry of Health (MS) declared an Emergency Situation of National Importance in Public Health in November 2015 due to the growing incidence of microcephaly. The emergency status was maintained by the MS until the end of 2016 (Brazil 2015; SVS 2016).

In early 2016, the World Health Organization (WHO) declared a Public Health Emergency of International Importance due to the wide dispersal of the Zika virus and its potential consequences, with autochthonous transmission occurring in 24 countries in the Americas and an 
estimated 2.5 billion people at risk of exposure (WHO 2016). In addition to the staggering increase in Zika cases highlighted by the media, Brazil continues to experience high incidence of Chikungunya and Dengue infections. Dengue undoubtedly remains among the most important arboviruses affecting humans in terms of morbidity and mortality (Fares et al 2015). In the last year alone, Brazil reported about $1,600,000$ cases and approximately 800 deaths, with $65 \%$ of all cases reported in the southeastern region (SVS 2015).

At the center of this triple epidemic is the mosquito Aedes (Stegomyia) aegypti Linnaeus, a vector of all three viral diseases. This species is present in all states of the Brazilian federation and approximately 4500 municipalities. It is a cosmopolitan species, found mainly in tropical and subtropical regions where climatic and social conditions are favorable to development (David et al 2009; Kraemer et al 2015).

Climatic factors contribute to the successful establishment of this vector, including adequate temperature for vector development and a rainy season, which favors production of breeding sites. Other factors contribute to vector success in dispersal, particularly the lack of urban infrastructure and basic sanitation, irregular occupation of areas, deficiency in garbage collection, irregular distribution of water, and lack of community awareness and participation. These factors also favor mosquito population growth and compromise vector control programs. David et al (2009) demonstrated that the degree of human organization and anthropogenic environmental modifications, local basic sanitation conditions, community industrialization, and even cultural habits can have a direct influence on Ae. aegypti occurrence and population density.

In this context, this work discusses aspects of the biology and success of the mosquito Ae. aegypti, in addition to the current main initiatives regarding control of this vector and the diseases it transmits.

\section{Aedes aegypti}

Aedes aegypti is a mosquito species native to Africa and currently widely distributed throughout the world (Fig 1). Some authors have suggested raising Stegomyia to the genus level, which would change the classification of this species to Stegomyia aegypti. This proposal has not yet been adopted as a general consensus; thus, we use the nomenclature $A e$. aegypti in this manuscript (Reinert et al 2004; Polaszek 2006; Wilkerson et al 2015). We also suggest that modification of the taxonomic status of an insect with great importance in public health and for which the general population is well informed may cause confusion, potentially hampering community support in vector control programs.

Aedes aegypti is the most synanthropic species of the Culicidae, always cohabiting with humans. It is preferentially diurnal and tends to be most active at dawn and dusk, thus avoiding the hottest periods of the day. Despite these clear behavioral preferences, this is an extremely opportunistic species that will bite in the day or night, and is known to occupy environments with conditions outside of the preferred range (Lourenço de Oliveira 2015).

Adults have black coloration with white markings and silver scales; however, they may present strong variation in tonality, sometimes with light brown coloration. The clypeus presents two prominent tufts of silver scales. The thorax is covered by dark and light scales, with silver scales forming longitudinal lines with a lyre-like shape. The external contour of this shape is formed by broader scales, while the central part, near the lyre-shaped pattern, formed by finer and more delicate lines (Forattini 2002).

Males are generally smaller than females; however, body size is not the ideal parameter for the sexual differentiation in this species because size is influenced by other external factors (e.g., food availability, larval density in breeding sites). Instead, prominent dimorphic features are present in antennal morphology (i.e., feathery in males and bristly in females) and structures of the buccal apparatus (i.e., long palps in males and short palps in females) (Consoli \& Oliveira 1994; Forattini 2002; Eiras 2011).

\section{Vector Biology}

The Aedes life cycle comprises four distinct phases: egg, larva, pupa, and adult (Fig 2). The eggs are small (about $0.5 \mathrm{~mm}$ ), elliptical, light colored at the time of oviposition, and darkening over time. Embryogenesis is complete in 2 or 3 days on average. When immersed in water eggs may hatch in minutes, but in the absence of water, high resistance to desiccation allows eggs to remain viable for weeks, months, or even over a year (Farnesi et al 2009; Faull \& Williams 2015).

We note not only that the number of viable eggs in the same location likely decreases over time but that the eggs that remain viable may be sufficient for local maintenance of the species when conditions are unfavorable for mosquito development (Juliano et al 2010). Silva \& Da Silva (1999) demonstrated that for Ae. aegypti kept in an environmental chamber at $28^{\circ} \mathrm{C}$ with mean humidity of $80 \%$, after 121 days, the hatch rate was $97.2 \%$. After 492 days, egg viability fell to $0.2 \%$.

Egg eclosion gives rise to larvae, which undergo four developmental instars comprising the only feeding stage for immatures and the only growth stage in the life cycle. The larvae of Ae. aegypti are aquatic and feed on suspended organic matter adhered to the walls or sediment at the bottom of the reservoirs. Larval feeding habits are non-selective, thus in addition to food particles larvae may readily ingest 


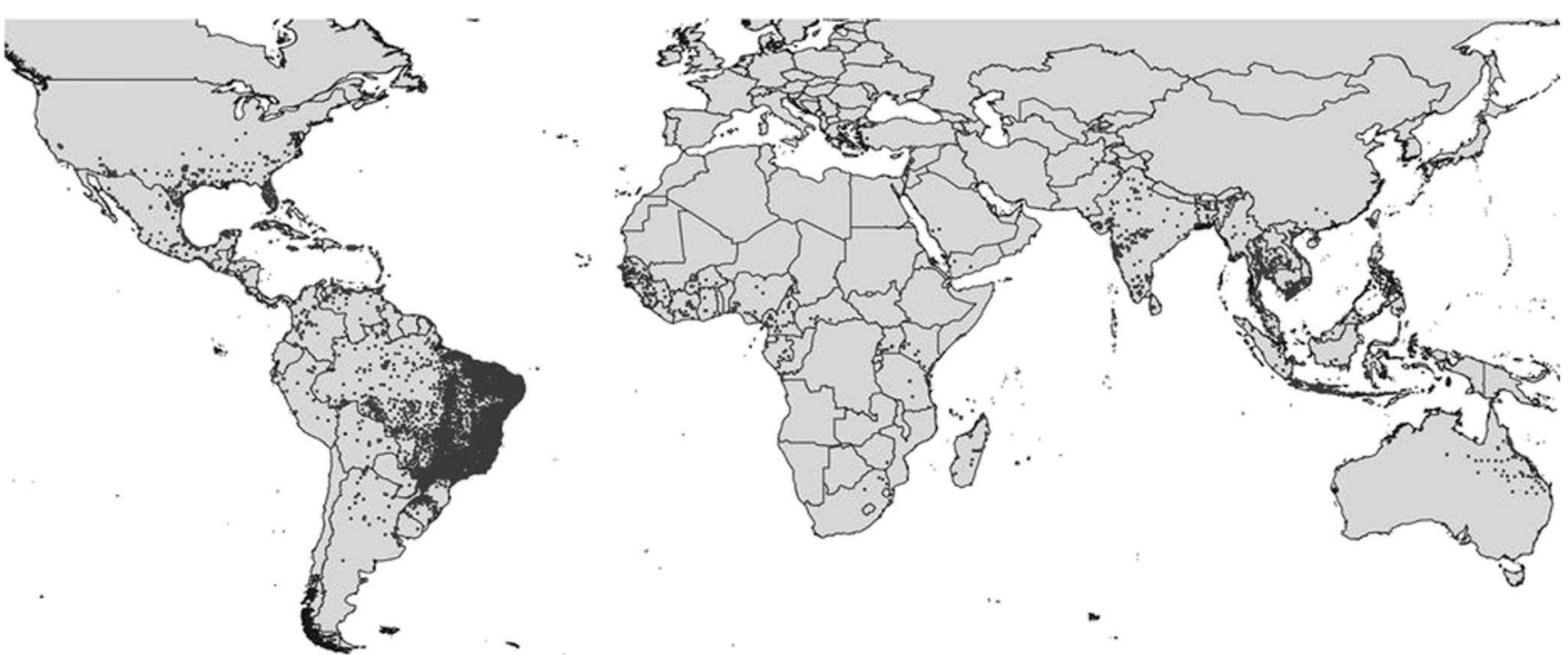

Fig 1 Global distribution of Aedes aegypti (data from 1960 to 2014). Adapted by Kraemer et al (2015). Link: http://www.nature.com/articles/ sdata201535.

chemical or biological insecticides (Lourenço de Oliveira et al 2015).

Aedes aegypti larvae breathe atmospheric air through spiracle openings on the siphon, located on the eighth abdominal segment. This behavior is a crucial consideration for vector control programs, as larvae must rise to the surface regularly to breathe. While on the surface, they become more detectable and, thus, more susceptible to control agents.

The development time for Ae. aegypti larvae is influenced by many factors, primarily temperature, food availability, and larval density in the breeding site. Under optimal conditions, larvae may complete all instars and enter the pupal stage in 4 to 5 days; however, the developmental period may be considerably prolonged under adverse conditions. The pupal phase is a non-feeding stage in which the mosquito undergoes a series of internal transformations that will culminate with adult formation. Pupae remain on the surface of the water almost continuously to breathe, diving to the bottom of the reservoir only when a threat is perceived. Under optimal temperature conditions (about $27^{\circ} \mathrm{C}$ ), the pupal phase has an average duration of 2 days; however, this period may be prolonged at lower temperatures. Pupal mortality rate is extremely low; thus, it is suggested that the number of pupae found in a reservoir corresponds directly to the number of adults that will emerge (Lourenço de Oliveira et al 2015).

Adults emerge slowly and remain on the water surface for several minutes, after which they fly in search of shelter. They typically seek humid areas that are protected from light and wind and, often, those near potential breeding sites. During this time, the exoskeleton hardens in both sexes, and rotation of genital structures occurs in males to facilitate

Fig 2 Aedes aegypti life cycle.

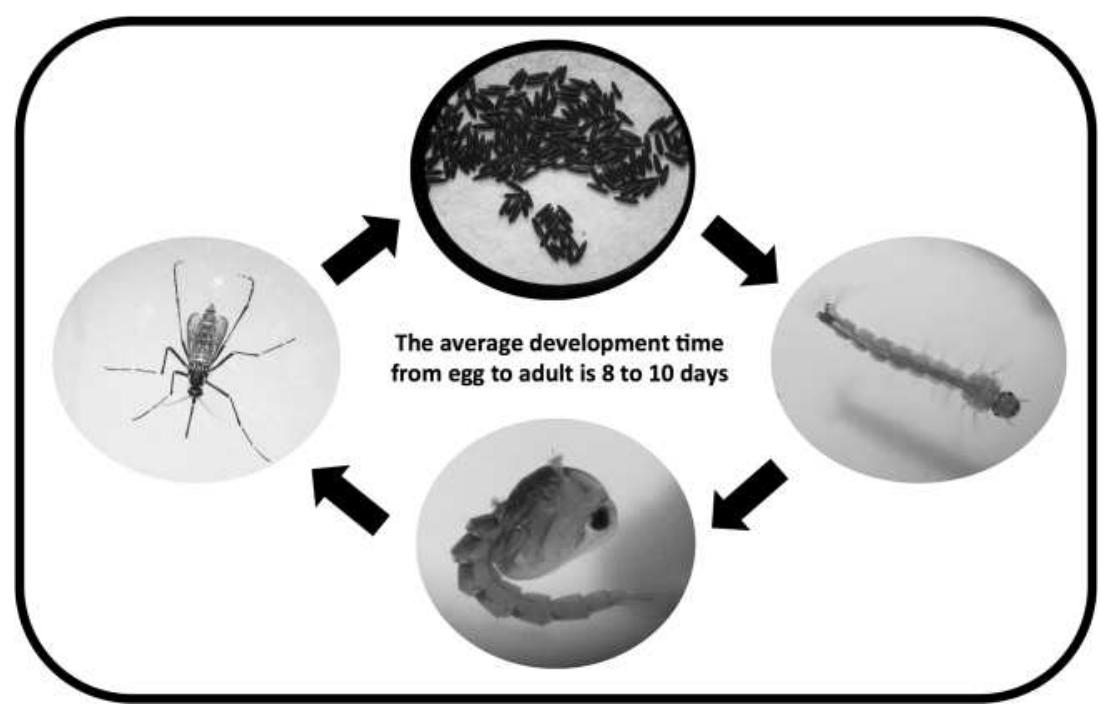


copulation. After copulation, females store seminal fluid in a structure called the spematheca, which allows sperm to remain viable indefinitely. Females may then produce fertile eggs for the remainder of their lifetime with no need for additional copulation (Forattini 2002; Lourenço de Oliveira et al 2015).

Adult males and females feed on sugary substances, mainly of vegetable origin. Females also require blood meals for maturation of the ovaries and consequent formation of eggs. Gravid females seek areas with accumulated standing water, preferably clean (with little decomposing organic matter), in which to lay eggs. Eggs are deposited individually by attachment to the wall of the reservoir, in a humid location just above the water surface. Some authors have also reported eggs placed directly on the surface of the water in field traps (Wermelinger et al 2015). When the water level in the reservoir rises, the eggs become inundated and hatch, reinitiating the cycle.

The general developmental cycle of Ae. aegypti consists of two phases: terrestrial and aquatic. Ecologically speaking, this is advantageous for the insect, as niche differentiation restricts intraspecific competition between adult and immature phases. Another important aspect is that immature stages are restricted to the oviposition site and unable to migrate; they are more vulnerable to control measures in these stages; control methods should thus preferably focus on the aquatic phase.

\section{Why is Aedes aegypti so Successful?}

Although Ae. aegypti does demonstrate behavioral and habitat preferences (e.g., active period in the day, temperature, water quality), they also display opportunistic behavior. This species frequently occurs in areas with suboptimal environmental conditions, will feed at any time of day, and can utilize water with large amounts of decomposing organic matter. They exhibit a high degree of plasticity, and can quickly adapt to different environmental conditions. These factors, in addition to having eggs that are highly resistant to desiccation, ensure the maintenance of the life cycle even in periods that are unfavorable for vector development.

The adaptation of this mosquito to areas with unfavorable water quality was recently been demonstrated by Paploski et al (2016), in a study carried out in four regions of Salvador, Bahia. Aedes aegypti larvae and adults were found in sewers in two of the four study regions; during the evaluations, almost $50 \%$ of the sewers had standing water and about 40\% contained Ae. aegypti larvae. Researchers also found Aedes albopictus Skuse and Culex quinquefasciatus Say in these environments. The importance of sewerage sites for reproduction in Aedes has already been described in other countries such as Colombia and Mexico (Andrade \& Cabrini
2007). This highlights the need for investigation of these types of breeding places in other areas of Brazil.

Aedes aegypti is well adapted to urban environments and prefers to occupy human dwellings. Data from the Ministry of Health of Brazil show that about $80 \%$ of the breeding sites are found in these urban domestic environments. Aedes aegypti also prefers man-made, artificial containers, bringing it in closer contact with humans (Brasil 2014). Generally, this species prefers containers that are colored or with dark interiors, typically in shady areas. This behavior is likely related to breeding success in these types of habitats, in addition to light aversion or photophobia of immature phases. This should be taken into consideration during home inspections, since larval occupation of these dark, shaded containers can make detection difficult for vector control services and residents.

Another important consideration for on-site inspection is that even very small containers or other breeding habitats cannot be disregarded as potential breeding sites (e.g., plastic cups, PET bottles, aluminum cans, small plant pots); $A e$. aegypti readily uses such sites, often transitionally, for reproduction. This is possible due to rapid development in this species, which allows adults to emerge before the water evaporates, avoiding larval mortality. Further, these types of water-holding containers are often involved in the passive dispersal of Ae. aegypti, because they are easily transported among locations and may retain eggs attached to inner surfaces. The focus on these breeding sites does not, however, diminish the importance of perennial breeding sites such as water tanks, since breeding habitats with higher waterholding capacity can continuously produce larger populations of mosquitoes.

The high reproductive capacity of $A$ e. aegypti is another factor that contributes to its success. A single female can lay approximately 100 eggs per gonotrophic cycle, making it difficult to control the vector in a given area (CDC 2016). One characteristic that, for instance, hinders control of Ae. aegypti is their habit of "skip oviposition." Females routinely distribute eggs among several breeding sites, making detection and complete elimination of breeding sites and eggs a nearly impossible task. Abreu et al (2015) demonstrated that a single female distributes eggs among an average of 4 to 6 breeding sites, and when conditions permit, will use up to 11. This is an important characteristic, as even a small number of eggs originating from a few adults may be enough to permit local persistence of mosquitoes and mosquitoborne diseases throughout the year.

Aedes aegypti has great epidemiological importance because in addition to being intimately associated with urban environments, it is highly anthropophilic, i.e., it prefers humans as a blood meal source (McBride et al 2014). Transovarial transmission may also occurs in this species, in which females transfer virus to their offspring. Although the 
contribution of vertical transmission is quite controversial (Zeidler et al 2008; Buckner et al 2013; Thangamani et al 2016), it might also contribute to the maintenance of circulating virus in the population.

The resistance of Ae. aegypti to them main chemical insecticides used for control is alarming, and makes control measures even more difficult. In Brazil, organophosphates were the only method used for many years to control Ae. aegypti. Intensified use following the 1986 epidemic and extending to the beginning of 2000 resulted in a strong selective pressure for resistance, and consequent decrease in the effectiveness of this group of insecticides. After 2000, organophosphates were replaced by pyrethroids for adult control. Unexpectedly, mosquito resistance to this new class of insecticides occurred extremely rapidly, with detected resistance in some populations as early as 2002 and 2003 (Valle et al 2015).

We emphasize that insecticides do not create resistant individuals, but that mutant alleles already exist naturally in populations. The widespread use of insecticides selects these resistant alleles, while eliminating those that are susceptible. This is the genetic basis of resistance. A major concern with respect to resistance is the intensity of selection pressure, which is caused mainly by the continuous use of a particular class of insecticide without frequent rotation and evaluation. This may have an irreversible effect on some populations, through the complete elimination of susceptible individuals (Crow 1957). Some authors also report risks involved in the use of domestic insecticides by the general population (Oliveira et al 2015a), noting that these products may also play a role in the selection of resistant mosquito populations.

\section{Main Control Strategies for Aedes aegypti}

According to the Ministry of Health National Guidelines for the Control of the Dengue Epidemic, Ae. aegypti in Brazil is primarily combatted using chemical, mechanical, and biological control methods (Brasil 2009). Some authors highlight the importance of adopting alternative measures for mosquito control (Maciel-de-Freitas et al 2012; Araújo et al 2015; Zara et al 2016). Currently, less conventional initiatives are being investigated to control the vector and the diseases it transmits, such as the use of Wolbachia bacteria to block transmission and the release of sterile transgenic mosquitoes to suppress wild populations.

\section{Chemical control}

Chemical control consists of the application of chemical compounds that can act against immature (larvicides) and adult phases (adulticides). It is and has been the main form of control for mosquitoes and other insect pests over centuries.
Although widely used to combat Ae. aegypti to the present day, chemical control has not been demonstratively effective in reducing vector populations. On the contrary, we have seen an increase in locations with mosquito infestation. Much of this problem is related to the misuse of chemicals, which in times of epidemics are used in larger quantities or over shorter intervals than recommended. Another problem is the use of the same product for several consecutive years, which is typically a result of management problems and the acquisition of a large quantity of product by control organizations. These and other factors have a direct impact upon the profile of mosquito resistance to these products.

The use of chemical insecticides carries other unintended negative consequences, such as the elimination of nontarget species, environmental contamination, accumulation of these products in the food chain, food contamination, and dangers to animal and human health. Misuse of these products may also lead to the "loss" of chemical molecules, and the exhaustion of possibilities for chemical control of these insects. The success of a chemical control program should be based on the monitoring of resistance profiles by location, on product rotation, and strategies to be used.

The chemical insecticides currently used for control of insect vectors of public health importance vary in mechanisms of action. Adults and larvae can be targeted using neurotoxic insecticides, while developmental regulators can be used against larvae. Organophosphates (larvae and adults), pyrethroids (adults), chitin synthesis inhibitors (larvae), and juvenile hormone analogues (larvae) are the most commonly used insecticide classes (Braga \& Valle 2007; Valle et al 2015).

In addition to traditional forms of insecticide application by fogging (ultralow volume) and direct application in reservoirs, other forms of product dispersal have been investigated. Among them, we highlight the use of mosquito dispersers of insecticides, devices with insecticides, and the use of insecticide-impregnated clothing and fabrics.

The use of mosquitoes as insecticide dispersers is a strategy that consists in attracting female Ae. aegypti to small containers treated with the insecticide pyriproxyfen, called "dissemination stations." When they come in contact with the insecticide particles in these reservoirs, the insecticide particles attach to their bodies and are passively transported to new oviposition sites. This contaminates the water in the reservoirs with insecticide, making the environment unfit for larval development and preventing adult emergence (Devine et al 2009; Abad-Franch et al 2015). According to this study, females can transport the insecticide to breeding sites up to $400 \mathrm{~m}$ from the dissemination station. The authors found a larval mortality rate of approximately $90 \%$ in breeding sites after the establishment of dissemination stations. Pyriproxyfen is an insect development regulator analogous to juvenile hormone, so it is non-toxic to humans. It is 
currently used by the Brazilian Ministry of Health as a conventional larvicide to combat dengue across the country (Abad-Franch et al 2015).

Another strategy that has already been evaluated is the use of devices with continuous release of insecticides. Studies performed in a domiciliary environment demonstrated that this strategy was effective at preventing mosquito bites, as well as to kill females. Mosquito biting behavior was nearly completely inhibited when exposed to 5 to $10 \%$ solutions of metofluthrin. This is a pyrethroid insect repellent, commonly used in devices known as emanators. Exposed females become disoriented and consequently seek shelter and rest. According to the authors, roughly $85 \%$ of the mosquitoes exposed to the device die in less than an hour. This device has a lifetime of approximately 20 days. Among the limitations of this technique, we highlight the difficulty of use in very large environments and the need for replacement after insecticidal effects cease (Rapley et al 2009; Ritchie \& Devine 2013).

Another common method of chemical insecticide use is impregnation of clothes and fabrics. This method is already used in military uniforms to avoid insect bites in the wild, and is now being adapted for use with school uniforms. This strategy aims to prevent mosquito bites in students, mainly during the class period, reducing the need for use of conventional repellents. Among the limitations of this method are continuous contact with the product, the difficulty of manufacturing and maintaining these uniforms, and that students are only protected on school days, during the class period (Wilder-Smith et al 2011, 2012; Tozan et al 2014).

Screens can also be impregnated with these products, in which case deltamethrin is typically used. These screens can be installed on doors and windows of homes, schools, and health facilities. Generally, this strategy has prioritized sites close to regions with the highest number of reported mosquito-borne infections. There are some limitations to this method, such as the difficulty of large-scale use and costs of screen installation and maintenance (Baly et al 2011, 2012, 2016). It is important to note that practically all of these methods can contribute to the selection of insecticideresistant mosquito populations.

\section{Mechanical control}

In general, mechanical control of mosquitoes consists of modifying the environment with the objective of eliminating, reducing, or avoiding the conditions necessary for population increase. For Ae. aegypti, this form of control should only be used in theory, because in practice, there is great difficulty in achieving widespread elimination of breeding sites and populations.

In general, the preferred breeding sites of Ae. aegypti are found inside houses, or in peridomiciliary areas near houses.
Breeding sites are usually found in shady locations, in reservoirs with dark coloration, and in accumulation of clean water. Very large collections of water (such as lakes) are avoided by this species, with most breeding sites being small to medium in size and often transitional. In the vast majority of cases, Ae. aegypti prefers to inhabit man-made containers. When potential breeding sites are encountered, the following question should be proposed: is it necessary? The answer to this question is often "no," in which case the breeding site should be disposed of. If the answer is "yes," then the necessary modifications should be made to eliminate the potential of the site for mosquito breeding.

Actions to limit breeding site potential include maintenance of water reservoirs (which should remain 100\% closed), potted plant trays (which should preferably be removed), tires (which should be discarded in a suitable place or kept in places that are protected from water), gutters (which must be kept clean and in perfect working order), and various containers, such as bottles, cans, jars, cups, and others (which should be disposed of properly). Special care should be taken with less obvious breeding sites, such as the drains in places seldom used (in which mosquitoes access should be blocked by screening or closure), trays behind some refrigerators (which must be screened or cleaned weekly), and any forgotten areas or structures in the home that are not frequently used and may hold water (they should be eliminated).

In periods of drought or in locations where water supply is irregular, it is of utmost importance to maintain water storage reservoirs. They must be kept $100 \%$ closed or screened, and openings in screens should be repaired to prevent entry and exit of mosquitoes. Valença et al (2013) concluded that this type of container may serve as a breeding site for mosquitoes in some regions. It is important to note that a poorly enclosed container can become a higher quality breeding site than a fully opened container, because partial closure (i.e., with holes or tears) protects and shades the environment while permitting mosquito entry and exit, and ideal situation for vector development.

Natural reservoirs are not of strong epidemiological importance in the maintenance, reproduction, and dispersal of Ae. aegypti; however, they should not be disregarded as some authors have reported encountering larvae in these sites (Varejão et al 2005; Gonçalves \& Messias 2008). In Brazil, Ae. aegypti larvae have been found in natural reservoirs such as bromeliads, tree holes, bamboos, and even rock holes; however, these encounters are extremely rare when compared to the preferential reservoir types (Consoli \& Lourenço de Oliveira 1994). Priority should thus be given to artificial reservoirs for detection and control of Ae. aegypti.

A study carried out in the Botanical Garden of Rio de Janeiro indicates that bromeliads do not constitute preferential foci of Ae. aegypti. A total of 120 bromeliads from ten 
different species were evaluated over the course of 1 year. Out of three thousand collected mosquito larvae and pupae, there were only two Ae. aegypti (0.07\%) and five Ae. albopictus (0.18\%) (Mocellin et al 2009). The authors emphasized that the Botanic Garden represents a transition area between the urban and the wild environment, and lies adjacent to the districts of Rio de Janeiro that are considered endemic for Dengue.

One proposal for mechanical control that deserves recognition is the "10 Minutes Against Aedes" campaign. This is an initiative that requests community participation in vector control by committing to spend 10 min per week identifying and removing possible breeding sites in the home. Weekly intervention eliminates adult production, because a week is typically not enough time for the mosquito to complete development from egg to adult, even under optimal conditions (which usually require 8 to 10 days). This proposal was conceived by researchers at the Oswaldo Cruz Foundation (Fiocruz), and is currently part of the control program in several states, including Rio de Janeiro and Minas Gerais (Fiocruz 2016a).

\section{Biological control}

Biological control employs natural enemies, including pathogens, predators, or parasitoids, with the potential to reduce populations of target species. Biological control of insect vectors such as Ae. aegypti has not been very successful despite the existence of a range of predators of immature stages, such as fish (Cavalcanti et al 2007) and larvae of other arthropods (Albeny et al 2011). This is because the success of biological control programs requires not only that the control agent feeds on the target prey but that the conditions are present to ensure efficient targeting of prey by natural enemies (e.g., seasonal synchronization with prey, adaptation to the same climatic conditions, selectivity, and use of the same habitat). Production of the control organism must also be practically feasible (e.g., high reproductive potential, ease of large-scale breeding) (Parra et al 2002; Van Lenteren 2009).

Predators such as fish can be used in the biological control of $A$. aegypti in some special cases, such as in small garden ponds, abandoned swimming pools, tanks for collecting rainwater, and other reservoirs that cannot be eliminated. This method cannot, however, be extended to the main breeding sites of the mosquito, such as plant dishes, water boxes, tires, gutters, and discarded drinking containers; its use is thus limited and impractical on a large scale.

In India, fish are commonly used to control mosquito vectors of diseases such as malaria (Chandra et al 2008; Kant et al 2013). Among the most common species are Poecilia reticulata, Xiphophorus maculatus, and Gambusia affinis, all exotic species. In the municipality of Alfenas, Minas Gerais,
$P$. reticulata and $X$. maculatus reduced or eliminated aquatic phases of Ae. aegypti in the evaluated reservoirs, with predation rates up to $100 \%$ for larvae and pupae (Brasil 2016). However, some authors warn of the risks of introducing nonnative fish such as Poecilia spp. in natural environments, such as risk of predation on native species and subsequent decline, as well as the potential to transmit diseases to native fish species (Shulse et al 2013; Azevedo-Santos et al 2016). The potential for lack of efficiency in the control of culicids should also be considered when assessing the costs and benefits of introduction.

The primary methods of biological control for Ae. aegypti utilize pathogens. Among the most common is the entomopathogenic bacteria Bacillus thuringiensis var. Israelis (Bti). These bacteria are commonly found in nature, and form spores and crystals that carry toxins with strong insecticidal activity. Bti has very high specificity, and is practically innocuous to humans and non-target fauna. Several studies have evaluated the action of Bti against Ae. aegypti, many with satisfactory results (Boyce et al 2013). Further, the combined action of the toxins produced by Bti is a positive factor for reducing the risk of acquired resistance in target populations (Andrade \& Cabrini 2007). Recently, a biolarvicide based on Bti was developed by the Oswaldo Cruz Foundation in partnership with the Brazilian company BR3. DengueTech ${ }^{\circledR}$ is a product capable of eliminating Ae. aegypti larvae in breeding sites in less than $24 \mathrm{~h}$, with residual action up to about 60 days (Fiocruz 2016b).

Among the limitations of Bti, environmental factors may interfere in insecticidal activity. Silva et al (2014) demonstrated that solar radiation, high temperature, and heavy rainfall negatively affected the efficiency of the commercial product VectoBac WG, a Bti-based biolarvicide. The authors concluded that the product was more effective in breeding sites protected from environmental factors, such as reservoirs in peridomiciliary areas. These results also indicate lower product effectiveness in regions with warmer climates.

\section{Use of wolbachia bacterium}

Wolbachia is a gram-negative Alphaproteobacteria from the order Rickettisiales that exhibits symbiotic relationships with its hosts (O'Neill et al 1992; Dumler et al 2001; Werren et al 2008). Wolbachia was first discovered in the reproductive tissues of Culex pipiens Linnaeus (Hertig \& Wolbach 1924) in 1924, and was subsequently named Wolbachia pipientis. However, due to the large number of strains and taxonomic uncertainties of the species, the scientific community today refers to it simply as Wolbachia (Lo et al 2007).

It is an obligate intracellular bacterium, maternally transmitted from mother to offspring. It is present in about $65 \%$ of the insects, including butterflies, moths, ants, crickets, locusts, termites, beetles, flies, and mosquitoes, among others 
(Hilgenboecker et al 2008; Oliveira et al 2015b). Wolbachia occurs in other non-insect invertebrates, such as arachnids (Gotoh et al 2003), crustaceans (Almerão et al 2012), and nematodes (Bandi et al 1998, 2001). It has never been found in vertebrates, and cannot be transmitted to humans (Popovici et al 2010).

One of the control strategies with Wolbachia involved the introduction of the bacterium into Ae. aegypti, a species in which the bacterium does not naturally occur, in order to block pathogens such as Dengue, Zika, and Chikungunya viruses. The potential of Wolbachia to block these and other pathogens has been described in a number of studies (Teixeira et al 2008; Hedges et al 2008; Moreira et al 2009; Walker et al 2011; Dutra et al 2016; Aliota et al 2016; Kamtchum-Tatuene et al 2016).

This line of research began in Australia with the successful transfer of Wolbachia from the fruit fly Drosophila melanogaster Meigen to Ae. aegypti using microinjection technique. This accomplishment took about 4 years and thousands of experimental attempts. After successful mosquito infection and establishment inside mosquito cells, Wolbachia stably persists in several mosquito tissues (Mcmeniman et al 2009).

After establishment of Wolbachia-infected Ae. aegypti colonies, trials were conducted in Australia in field and semi-field conditions to evaluate the potential for transfer to wild mosquitoes. A few weeks after release of these mosquitoes in the field, the proportion of mosquitoes with Wolbachia infection was nearly $100 \%$ of the test population (Walker et al 2011; Hoffmann et al 2011). Further, after roughly 5 years in the field with no further interventions, nearly $100 \%$ of the population still host Wolbachia, and the bacteria continues to block Dengue virus infection (Hoffmann et al 2014; Frentiu et al 2014), which demonstrates the safety of the method.

This invasion of infected mosquitoes is possible due to the reproductive manipulation of their hosts by Wolbachia, called cytoplasmic incompatibility (Cl). Infected females always generate infected offspring, regardless of the infection status of male mates. When uninfected females mate with infected males, the fertilized eggs die and there is no generation of offspring. Thus, $75 \%$ of the possible crosses favor Wolbachia, either directly through generation of infected offspring or indirectly through preventing production of uninfected offspring (Fig 3).

An international non-profit initiative called Eliminate Dengue: Our Challenge has been trialing in several countries and involves the release of Ae. aegypti containing Wolbachia to replace wild mosquito populations and, therefore, reduce the transmission of arboviroses. In Brazil, the project is conduct by the Oswaldo Cruz Foundation and supported by the Ministry of Health ("Eliminar a Dengue: Desafio Brasil"). Wolbachia-containing Ae. aegypti were brought from

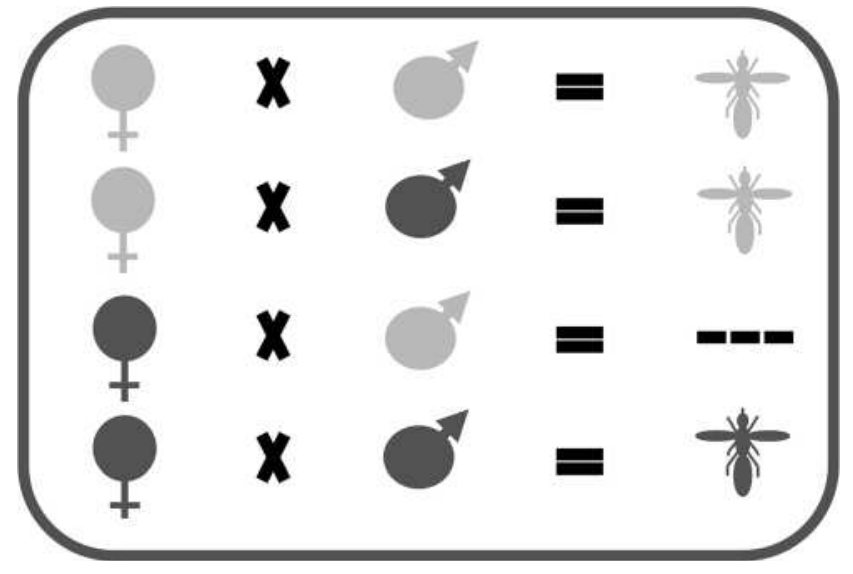

Fig 3 The simplified representative scheme of possible genetic crosses and the mechanism of cytoplasmic incompatibility in Aedes aegypti mosquitoes. Light gray symbols represent mosquitoes infected with Wolbachia, dark gray symbols represent uninfected mosquitoes, and the dashed line indicates no production of offspring.

Australia and backcrossed with Brazilian mosquitoes for several generations in order to insert Wolbachia into lab colonies while maintaining the genetic characteristics of local populations, following a model proposed by Yeap et al (2011). Field tests to evaluate the dispersal of mosquitoes with Wolbachia into wild populations in Brazil are being carried out in areas of Rio de Janeiro. Results indicate that a few weeks after release of a small number of infected mosquitoes, field populations reached infection averages near $90 \%$. In addition to Australia and Brazil, Vietnam and Indonesia have been testing release of Wolbachia-infected mosquitoes and are finding similar results. Experiments are also under way in Medellín, Colombia (Callaway 2016).

There are a few points on the safety of the technique that should be highlighted. First, Wolbachia is an intracellular bacterium that cannot survive outside the insect cell, i.e., when the mosquito dies, it also dies. Researchers have determined that Wolbachia is not present in Ae. aegypti saliva. This is because the bacterium is not able to cross the narrow salivary duct of the mosquito, since mosquito cells are on the scale of approximately $10 \mu \mathrm{m}$, while the buccal apparatus of the insect salivary duct has a width of only $1 \mu \mathrm{m}$. Another factor that should be considered is that humans have been in contact with generations of Wolbachia-infected C. quinquefasciatus and Ae. albopictus, and thus far, no negative effects from bites have ever been reported. Moreover, researchers from the Eliminate Dengue Program in Australia voluntarily offered themselves as blood hosts for a Wolbachia-infected colony over a 5-year period, resulting in thousands of mosquito bites among them; there were no detectable negative results. Finally, it is worth highlighting that authorization by (competent) governing organizations in each country was required prior to initiation of field trials, and this bolsters the safety of the technique. Thoughtful engagement of community members is also carried out to 
gain majority support of the community before the release of infected mosquitoes. The greatest challenge regarding the use of Wolbachia as a strategy to block disease transmission by Ae. aegypti is expanding the proposal for use in large areas (Dutra et al 2015; Caragata et al 2016).

Another line of Wolbachia research proposes the release of infected males with the aim of suppressing wild mosquitoes through the mechanism of cytoplasmic incompatibility. To this end, studies are being carried out in the USA, Singapore, China, and French Polynesia for potential suppression of Ae. aegypti and Ae. albopictus (Callaway 2016).

The use of Wolbachia strategy to replace mosquito population has the potential of significantly decrease the transmission of several arboviroses in one given area and can easily be used in an integrated manner with other strategies. It has been recently reported that temperature can reduce Wolbachia load in mosquitoes (Ross et al 2017), which in turn could potentially reduce its blocking potential. It is important to emphasize that Ae. aegypti mosquitoes live inside dwellings and preferably stay in cooler environments where temperatures are much lower than the outside environmental temperature. Therefore, it is important to study the variance of Wolbachia density in mosquitoes as close as to the mosquito living habitats, instead of stable temperature incubators. Furthermore, the risk of reduced blocking effect by a fraction of the released Wolbachia mosquito population has been shown through mathematical modeling based on vector competence data from dengue patients (Ferguson et al 2015). Wolbachia can reduce from $66-75 \%$ the Ro for dengue, which, in a normal epidemic setting, would eliminate the disease transmission.

\section{Sterile insect technique}

This technique is based on the sterilization of male insects by irradiation. When released in the field, they mate with females and the cross produces inviable offspring, suppressing the population. The irradiation consists of minimal doses of $\mathrm{X}$-rays or gamma rays, after which random chromosomal rearrangements occur that are capable of provoking sterilization in males. Studies involving male sterilization by irradiation began in the 1960s, and the first targets of this technique were insect agricultural pests (Knipling 1955), such as the fruit fly Ceratitis capitata Wiedemann.

Despite the success of sterile insect technique (SIT) in agricultural pests, some authors suggest that the use of this technique in Ae. aegypti is difficult to practically impossible. Ferreira et al (2008) argue that this is mainly due to heterogeneous spatial distribution of breeding sites and mosquito breeding behavior. In addition, Valle et al (2015) point out that mosquitoes are very small, delicate insects which are not very resistant to irradiation and difficult to manipulate, making them unsuitable organisms for this methodology.
Despite these limitations, some authors support the possibility of SIT application as a method of control for mosquito vectors, and suggest this alternative as a strategy to avoid or decrease the use of chemical insecticides (Alphey et al 2010, 2013).

Genetically modified mosquitoes carrying lethal gene- RIDL

Another technique that is based on the use of sterile males, known as an "evolution" of SIT, is the release of insects carrying a dominant lethal gene (RIDL). The method consists of release of sterile male Ae. aegypti carrying a lethal gene for offspring, which functions by producing a protein that prevents offspring from reaching adulthood. In addition to the lethal gene, these mosquitoes also have a fluorescent gene for identification under ultraviolet light (Oliveira et al 2011). This technology was developed in 2002 by researchers at the University of Oxford in the UK, and was realized through microinjection of the two specific genes into Ae. aegypti DNA (producing the OX513A strain). This mosquito is produced in the laboratory by the British company Oxitec, separated, and released in large quantities in the field. Males carrying the lethal gene mate with wild females, which then generate inviable offspring. A large number of mosquitoes must be released because OX513A males have reduced fitness compared to wild mosquitoes, and may only survive about 5 days. To allow these mosquitoes to reproduce and generate viable offspring in the lab, an antidote is deployed (tetracycline antibiotic) via supplementing along with insect feed (Fig 4).

Tests with these transgenic mosquitoes in Brazil were initiated in Bahia state in the cities of Jacobina and Juazeiro, and resulted in an $80-95 \%$ reduction of wild mosquito populations (Carvalho et al 2015; Oxitec Brasil 2016). In 2015, the

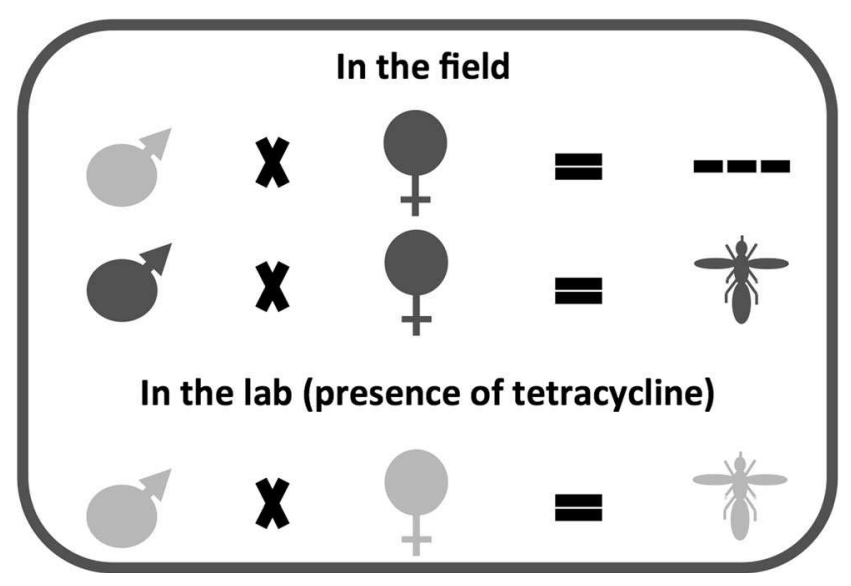

Fig 4 Simplified representative scheme of crosses involving transgenic Aedes aegypti mosquitoes. Light gray symbols represent transgenic mosquitoes carrying the lethal gene, dark gray symbols represent mosquitoes without the lethal gene, and the dashed line indicates inviable offspring. 
project started in the city of Piracicaba, São Paulo. According to Oxitec, preliminary results showed an $82 \%$ reduction of larvae in the wild Ae. aegypti population. In addition, in the same period, a $91 \%$ drop in dengue cases in this region was reported. Similar results were also found following the release of OX513A in the Cayman Islands in 2010, with $80 \%$ suppression of the wild mosquito population (Harris et al 2011, 2012). These studies demonstrate the potential of this technology for suppression of wild Ae. aegypti populations.

Several difficulties have been encounter in the use of transgenic Aedes. First, the large number of mosquitoes necessary for release is prohibitive. For transgenic mosquitoes to be effective, an estimated 10 transgenic mosquitoes should be released for each wild mosquito, which requires release of approximately 20 million mosquitoes per week in a small area (e.g., a town of about 10,000 inhabitants) in the first 4 to 6 months of the protocol. The constant release events are non-sustainable due to high cost, and because separation of sexes is not perfect, a small number of females may be released (less than $0.05 \%$ ). Further, about $5 \%$ of the mosquitoes can survive the lethal gene, and the general population is hesitant to support transgenic mosquito release (Oxitec Brasil 2016; Wallace 2013).

\section{Final Considerations}

The success of Ae. aegypti with respect to development and reproduction, diversity of breeding sites, high dispersal capability, colonization of urban environment, and the transmission of diseases is becoming increasingly clear. This highlights the importance and necessity of using all available tools for controlling Ae. aegypti populations and, consequently, the diseases they transmit. The community support of initiatives as well as the interconnection among the various tools available are crucial for successfully combating this vector, particularly in light of the triple epidemic that Brazil is currently experiencing.

Several factors should be considered to enhance effectiveness of current control programs, including compatibility with other techniques, safety of the proposal, sustainability, selectivity, cost-effectiveness, and feasibility for large-scale production and implementation. Issues such as basic sanitation, adequate residual and solid waste management, regular water supply, health education, globalization, tourism, and the intense human movement are factors that should be prioritized, and these issues should be addressed within and linked to public health policy as a strategy for forming sound proposals that include all sectors of society.

There is also an obvious need for alternative methods of mosquito vector control. In February 2016, the Ministry of Health published a technical note suggesting that pilot projects using the release of Wolbachia-infected and transgenic mosquitoes should be carried out in Brazil. This has also been suggested by the World Health Organization.

Our attention should be focused on the possibility of new epidemics, as well as the entry of other pathogens into the country. We are currently on alert with the possible entry of a new virus or strain of the Mayaro virus in South America. Although the disease is transmitted primarily by wild mosquitoes of the genus Haemagogus, there is a great deal of concern about the possibility of viral adaptation to urban vectors such as Ae. aegypti.

Finally, the fight against Aedes must be continuous, with integrated control actions executed steadily through all seasons, not only during periods of abundant rain and high heat. The fight against this medically important vector should be maintained by the government and should attain year-round community support. With our participation, we can reduce the adaptive success of $A e$. aegypti, thereby reducing the impact of arboviruses on human populations.

Acknowledgments We want to acknowledge all the present and past members of the Mosquitos Vetores Group at the Centro de Pesquisa René Rachou/Fundação Oswaldo Cruz (CPqRR/Fiocruz) for important daily discussions.

\section{References}

Abad-Franch F, Zamora-Perea E, Ferraz G, Padilla-Torres SD, Luz SLB (2015) Mosquito-disseminated pyriproxyfen yields high breeding-site coverage and boosts juvenile mosquito mortality at the neighborhood scale. PLoS Negl Trop Dis 9:1-17

Abreu FVS, Morais MM, Ribeiro SP, Eiras AE (2015) Influence of breeding site availability on the oviposition behaviour of Aedes aegypti. Mem Inst Oswaldo Cruz 110:669-676

Albeny DS, Martins GF, Andrade MR, Krüger RF, Vilela EF (2011) Aedes aegypti survival in the presence of Toxorhynchites violaceus (Diptera: Culicidae) fourth instar larvae. Zool 28:538-540

Aliota MT, Walker EC, Uribe Yepes A, Dario Velez I, Christensen BM, Osorio JE (2016) The wMel strain of Wolbachia reduces transmission of Chikungunya virus in Aedes aegypti. PLoS Negl Trop Dis 10:1-13

Almerão MP, Fagundes NJR, De Araújo PB, Verne S, Grandjean F, Bouchon D, Araújo AM (2012) First record of Wolbachia in South American terrestrial isopods: prevalence and diversity in two species of Balloniscus (Crustacea, Oniscidea). Genet Mol Biol 35:980-989

Alphey L, Benedict M, Bellini R, Clark GG, Dame D, Service MW, Dobson SL (2010) Sterile-insect methods for control of mosquito-borne diseases: an analysis. Vector Borne Zoonotic Dis 10:295-311

Alphey L, McKemey A, Nimmo D, Neira Oviedo M, Lacroix R, Matzen K, Beech C (2013) Genetic control of Aedes mosquitoes. Pathog Glob Health 107:170-179

Andrade CFS, Cabrini I (2007) Controle de pernilongos e borrachudos em áreas urbanas. In: Pinto AS, Rossi MM (eds) Salmeron E Manejo de pragas urbanas. ESALQ, Piracicaba, pp 55-66

Araújo HRC, Carvalho DO, loshino RS, Costa-da-Silva AL, Capurro ML (2015) Aedes aegypti Control strategies in Brazil: incorporation of new technologies to overcome the persistence of dengue epidemics. Insects 6:576-594 
Azevedo-Santos V, Vitule J, García-Berthou E, Pelicice FM, Simberloff D (2016) Misguided strategy for mosquito control. Science 351:675

Baly A, Flessa $S$, Cote $M$, Thiramanus $T$, Vanlerberghe $V$, Villegas $E$, Jirarojwatana S, Van Der Stuyft P (2011) The cost of routine Aedes aegypti control and of insecticide-treated curtain implementation. AmJTrop Med Hyg 84:747-752

Baly A, Toledo ME, Rodriguez K, Benitez JR, Rodriguez M, Boelaert M, Vanlerberghe V, Van der Stuyft P (2012) Costs of dengue prevention and incremental cost of dengue outbreak control in Guantanamo, Cuba. Trop Med Int Heal 17:123-132

Baly A, Toledo ME, Lambert I, Benítez E, Rodriguez K, Rodriguez E, Vanlerberghe V, Van der Stuyft P (2016) Cost of intensive routine control and incremental cost of insecticide-treated curtain deployment in a setting with low Aedes aegypti infestation. Rev Soc Bras Med Trop 49:418-424

Bandi C, Anderson TJ, Genchi C, Blaxter ML (1998) Phylogeny of Wolbachia in filarial nematodes. Proc R Soc London Biol Sci 265: 2407-2413

Bandi C, Trees AJ, Brattig NW (2001) Wolbachia in filarial nematodes: evolutionary aspects and implications for the pathogenesis and treatment of filarial diseases. Vet Parasitol 98:215-238

Boyce R, Lenhart A, Kroeger A, Velayudhan R, Roberts B, Horstick O (2013) Bacillus thuringiensis israelensis (Bti) for the control of dengue vectors: systematic literature review. Trop Med Int Heal 18:564-577

Braga IA, Valle D (2007) Aedes aegypti: inseticidas, mecanismos de ação e resistência. Epidemiol e Serviços Saúde 16:279-293

Brasil (2009) Diretrizes Nacionais para a prevenção e controle de epidemias de dengue. Ministério da Saúde - Secretaria de Vigilância em Saúde, Séria A. Normas e Manuais Técnicos, Brasília, p 160

Brasil (2014) Dengue: 117 municípios em situação de risco e 533 em alerta. http://portalsaude.saude.gov.br/index.php/o-ministerio/ principal/secretarias/svs/noticias-svs/15477-ms-atualiza-dados-sobreinfestacao-do-mosquito-em-municipios. Accessed 10 Nov 2016

Brasil (2015) Governo aciona ações de emergência diante da alta de casos de microcefalia em PE. http://www.brasil.gov.br/saude/2015/ 11/governo-aciona-acoes-de-emergencia-diante-de-alta-de-casos-demicrocefalia-em-pe. Accessed 10 Nov 2016

Brasil (2016) Alfenas usa peixes no combate ao Aedes aegypti. http:// www.blog.saude.gov.br/index.php/combate-ao-aedes/50590alfenas-usa-peixes-no-combate-ao-aedes-aegypti. Accessed 10 Nov 2016

Buckner EA, Alto BW, Lounibos LP (2013) Vertical transmission of Key West dengue-1 virus by Aedes aegypti and Aedes albopictus (Diptera: Culicidae) mosquitoes from Florida. J Med Entomol 50:1291-1297

Callaway E (2016) Rio fights Zika with biggest release yet of bacteriainfected mosquitoes. Nature 539:17-18

Caragata EP, Dutra HLC, Moreira LA (2016) Exploiting intimate relationships: controlling mosquito-transmitted disease with Wolbachia. Trends Parasitol 32:207-218

Carvalho DO, McKemey AR, Garziera L, Lacroix R, Donnelly CA, Alphey L, Malavasi A, Capurro ML (2015) Suppression of a field population of Aedes aegypti in Brazil by sustained release of transgenic male mosquitoes. PLoS Negl Trop Dis 9:1-15

Cavalcanti LPG, Soares Pontes RJ, Ferreira Regazzi AC, de Paula FJ, Frutuoso RL, Sousa EP, Dantas Filho FF, de Oliveira Lima JW (2007) Competência de peixes como predadores de larvas de Aedes aegypti, em condições de laboratório. Rev Saude Publica 41:638-644

CDC (2016) Mosquito life cycle. http://www.cdc.gov/dengue/resources/ factSheets/MosquitoLifecycleFINAL.pdf. Accessed 14 Nov 2016

Chandra G, Bhattacharjee I, Chatterjee SN, Ghosh A (2008) Mosquito control by larvivorous fish. Indian J Med Res 127:13-27

Consoli RAGB, Lourenço de Oliveira R (1994) Principais mosquitos de importância sanitária no Brasil. Fiocruz, Rio de Janeiro, p 228

Crow JF (1957) Genetics of insect resistance to chemicals. Annu Rev Entomol 2:227-246
David MR, Lourenço-de-Oliveira R, De Freitas RM (2009) Container productivity, daily survival rates and dispersal of Aedes aegypti mosquitoes in a high income dengue epidemic neighbourhood of Rio de Janeiro: presumed influence of differential urban structure on mosquito biology. Mem Inst Oswaldo Cruz 104:927-932

Devine GJ, Perea EZ, Killeen GF, Stancil JD, Clark SJ, Morrison AC (2009) Using adult mosquitoes to transfer insecticides to Aedes aegypti larval habitats. Proc Natl Acad Sci 106:11530-11534

Dumler JS, Barbet AF, Bakker CP, Dasch GA, Palmer GH, Ray SC, Rikihisa $Y$, Rurangwira FR (2001) Reorganization of gene in families Rickettsiaceae and Anaplasmataceae in the order Rickettsiales: unification of some species of Ehrlichia with Anaplasm, Cowdria with Ehriichia with neorickettsia, description of six new species combinations and designatio. Int J Syst Evol Microbiol 51:2145-2165

Dutra HLC, dos Santos LMB, Caragata EP, Silva JBL, Villela DAM, Macielde-Freitas RM, Moreira LA (2015) From lab to field: the influence of urban landscapes on the invasive potential of Wolbachia in Brazilian Aedes aegypti mosquitoes. PLoS Negl Trop Dis 9:1-22

Dutra HLC, Rocha MN, Dias FBS, Mansur SB, Caragata EP, Moreira LA (2016) Wolbachia blocks currently circulating Zika virus isolates in Brazilian Aedes aegypti mosquitoes. Cell Host Microbe 19:771-774

Eiras AE (2011) Culicidae. In: Neves DP (ed) Parasitologia Humana. Atheneu, São Paulo, pp 387-401

Fares RCG, Souza KPR, Añez G, Rios M (2015) Epidemiological scenario of dengue in Brazil. Biomed Res Int 2015:1-13

Farnesi LC, Martins AJ, Valle D, Rezende GL (2009) Embryonic development of Aedes aegypti (Diptera: Culicidae): influence of different constant temperatures. Mem Inst Oswaldo Cruz, Rio de Janeiro 104(1): $124-126$

Faull KJ, Williams CR (2015) Intraspecific variation in desiccation survival time of Aedes aegypti (L.) mosquito eggs of Australian origin. J Vector Ecol 40:292-230

Ferguson NM, Kien DT, Clapham H, Aguas R, Trung VT, Chau TN, Popovici J, Ryan PA, O'Neill SL, McGraw EA, Long VT, Dui le T, Nguyen HL, Chau NV, Wills B, Simmons CP (2015) Modeling the impact on virus transmission of Wolbachia-mediated blocking of dengue virus infection of Aedes aegypti. Sci Transl Med 7(279):279-237

Ferreira CP, Yang HM, Esteva L (2008) Assessing the suitability of sterile insect technique applied to Aedes aegypti. J. Biol. Syst. 16:565

Fiocruz (2016a) 10 Minutos contra o Aedes. http://www.ioc.fiocruz.br/ dengue/textos/1ominutos.html. Accessed 16 Nov 2016

Fiocruz (2016b) Fiocruz apresenta DengueTech em congresso nacional de saúde. http://www.ioc.fiocruz.br/dengue/textos/1ominutos.html. Accessed 16 Nov 2016

Forattini OP (2002) Culicidologia Médica. Edusp, São Paulo, p 860

Frentiu FD, Zakir T, Walker T, Popovici J, Pyke AT, Van den Hurk A, McGraw EA, O'Neill SL (2014) Limited dengue virus replication in field-collected Aedes aegypti mosquitoes infected with Wolbachia. PLoS Negl Trop Dis 8:1-10

Gonçalves KS, Messias MC (2008) Ocorrência de Aedes (Stegomyia) aegypti (Linnaeus, 1762) (Insecta, Diptera, Culicidae) em bromélias, no município do Rio de Janeiro (Rio de Janeiro, Brasil). Biota Neotrop 8:235-237

Gotoh T, Noda H, Hong XY (2003) Wolbachia distribution and cytoplasmic incompatibility based on a survey of 42 spider mite species (Acari: Tetranychidae) in Japan. Heredity 91(3):208-216

Harris AF, Nimmo D, McKemey AR, Kelly N, Scaife S, Donnelly CA, Beech $C$, Petrie WD, Alphey $L$ (2011) Field performance of engineered male mosquitoes. Nat Biotechnol 29:1034-1037

Harris AF, McKemey AR, Nimmo D, Curtis Z, Black I, Morgan AS, Oviedo MN, Lacroix R, Naish N, Morrison NI, Collado A, Stevenson J, Scaife S, Dafa'alla T, Fu G, Phillips C, Miles A, Raduan N, Kelly N, Beech C, Donnelly CA, Petrie WD, Alphey L (2012) Successful suppression of a field mosquito population by sustained release of engineered male mosquitoes. Nature $30: 828-830$ 
Hedges LM, Brownlie JC, O'Neill SL, Johnson KN (2008) Wolbachia and virus protection in insects. Science (80- ) 322:702

Hertig M, Wolbach SB (1924) Studies on Rickettsia-Like Micro-Organisms in Insects. J Med Res. 44(3):329-374

Hilgenboecker K, Hammerstein P, Schlattmann P, Telschow A, Werren JH (2008) How many species are infected with Wolbachia?-a statistical analysis of current data. FEMS Microbiol Lett 281:215-220

Hoffmann AA, Montgomery B, Popovici J, Iturbe-Ormaetxe I, Johnson PH, Muzzi F, Greenfield M, Durkan M, Leong YS, Dong Y, Cook $H$, Axford J, Callahan AG, Kenny N, Omodei C, McGraw EA, Ryan PA, Ritchie AS, Turelli M, O'Neill SL (2011) Successful establishment of Wolbachia in Aedes populations to suppress dengue transmission. Nature 476:454-457

Hoffmann AA, Iturbe-Ormaetxe I, Callahan AG, Phillips BL, Billington $\mathrm{K}$, Axford JK, Montgomery B, Turley AP, O'Neill SL (2014) Stability of the wMel Wolbachia infection following invasion into Aedes aegypti populations. PLoS Negl Trop Dis 8:e3115

Juliano SA, Meara GFO, Cutwa MM (2010) Competing Mosquitoes 130: 458-469

Kamtchum-Tatuene J, Makepeace BL, Benjamin L, Baylis M, Solomon T (2016) The potential role of Wolbachia in controlling the transmission of emerging human arboviral infections. Curr Opin Infect Dis 29:1-9

Kant R, Haq S, Srivastava HC, Sharma VP (2013) Review of the bioenvironmental methods for malaria control with special reference to the use of larvivorous fishes and composite fish culture in central Gujarat, India. J Vector Borne Dis 50:1-12

Knipling EF (1955) Possibilities of insect control or eradication through the use of sexually sterile males. J Eco Entomol 48:459-462

Kraemer MUG, Sinka ME, Duda KA, Mylne A, Shearer FM, Brady OJ, Messina JP, Barker CM, Moore CG, Carvalho RG, Coelho GE, Van Bortel W, Hendrickx G, Schaffner F, Wint GRW, Elyazar IRF, Teng HJ, Hay SI (2015) The global compendium of Aedes aegypti and Aedes albopictus occurrence. Sci Data 2:150035

Lo N, Paraskevopoulos C, Bourtzis K, O'Neill SL, Werren JH, Bordenstein SR, Bandi C (2007) Taxonomic status of the intracellular bacterium Wolbachia pipientis. Int J Syst Evol Microbiol 57:654-657

Lourenço de Oliveira R (2015) Biologia e comportamento do vetor. In: Valle $D$ (ed) Dengue: teorias e práticas. Fiocruz, Rio de Janeiro, pp 7592

Maciel-de-Freitas R, Aguiar R, Bruno RV, Guimarães MC, Lourenço-deOliveira R, Sorgin MHF, Struchiner CJ, Valle D, O'Neill SL, Moreira LA (2012) Why do we need alternative tools to control mosquito-borne diseases in Latin America? Mem Inst Oswaldo Cruz 107:828-829

McBride CS, Baier F, Omondi AB, Spitzer AS, Lutomiah J, Sang R, Ignell R, Vosshall LB (2014) Evolution of mosquito preference for humans linked to an odorant receptor. Nature 515:222-227

McMeniman CJ, Lane RV, Cass BN, Fong AWC, Sidhu M, Wang YF, O'Neill SL (2009) Stable introduction of a life-shortening Wolbachia infection into the mosquito Aedes aegypti. Science 323:141-144

Mocellin MG, Simões TC, Nascimento TFS do, Teixeira MLF, Lounibos LP, Oliveira RL (2009) Bromeliad-inhabiting mosquitoes in an urban botanical garden of dengue endemic Rio de Janeiro-are bromeliads productive habitats for the invasive vectors Aedes aegypti and Aedes albopictus? Mem Inst Oswaldo Cruz 104:1171-1176

Moreira LA, Iturbe-Ormaetxe I, Jeffery JA, Lu G, Pyke AT, Hedges LM, Rocha BC, Hall-Mendelin S, Day A, Riegler M, Hugo LE, Johnson KN Kay BH, McGraw EA, van den Hurk AF, Ryan PA, O'Neill SL (2009) A Wolbachia symbiont in Aedes aegypti limits infection with Dengue, Chikungunya, and Plasmodium. Cell 139:1268-1278

O'Neill SL, Giordano R, Colbert AM, Karr TL, Robertson HM (1992) 16S rRNA phylogenetic analysis of the bacterial endosymbionts associated with cytoplasmic incompatibility in insects. Proc Natl Acad Sci U S A 89:2699-2702

Oliveira SDL, Carvalho DO, Capurro ML (2011) Mosquito transgênico: do paper para a realidade. Rev da Biol 6b:38-43
Oliveira LB, Maria R, Nunes P, Santana M, Rosa A, Mariana N, Nunes F, Bantim I, Calou F, Peron AP, Maria M, Marques M, Michel P, Ferreira P (2015a) Perfil do uso populacional de inseticidas domésticos no combate a mosquitos Profile of the population use of household insecticides against mosquitoes. Semin Ciências Biológicas e da Saúde 36:79-92

Oliveira CD, Gonçalves DS, Baton L, Shimabukuro PHF, Carvalho FD, Moreira LA (2015b) Broader prevalence of Wolbachia in insects including potential human disease vectors. Bull Entomol Res 105:305315

Oxitec Brasil (2016) Conheça os resultados dos projetos que usaram a tecnologia do Aedes do Bem e reduziram a população selvagem do mosquito transmissor da dengue, Zika e chikungunya. http://br. oxitec.com/. Accessed em 25 Nov 2016

Paploski IAD, Rodrigues MS, Mugabe VA, Kikuti M, Tavares AS, Reis MG, Kitron U, Ribeiro GS (2016) Storm drains as larval development and adult resting sites for Aedes aegypti and Aedes albopictus in Salvador, Brazil. Parasit Vectors 9:1-8

Parra JRP, Botelho PSM, Correa-Ferreira BS, Bento JMS (2002) Controle biológico no Brasil: parasitoides e predadores. Manole, São Paulo, $p$ 609

Polaszek A (2006) Two words colliding: resistance to changes in the scientific names of animals-Aedes vs Stegomyia. Trends Parasitol 22(1):8-9

Popovici J, Moreira LA, Poinsignon A, Iturbe-Ormaetxe I, McNaughton D, O'Neill SL (2010) Assessing key safety concerns of a Wolbachia-based strategy to control dengue transmission by Aedes mosquitoes. Mem Inst Oswaldo Cruz 105:957-964

Rapley LP, Russell RC, Montgomery BL, Ritchie SA (2009) The effects of sustained release metofluthrin on the biting, movement, and mortality of Aedes aegypti in a domestic setting. AmJTrop Med Hyg 81:9499

Reinert JF, Harbach RE, Kitching IJ (2004) Phylogeny and classification of Aedini (Diptera: Culicidae), based on morphological characters of all life stages. Zool J Linnean Soc 142:289-368

Ritchie SA, Devine GJ (2013) Confusion, knock-down and kill of Aedes aegypti using metofluthrin in domestic settings: a powerful tool to prevent dengue transmission? Parasit Vectors 6:262

Ross PA, Wiwatanaratanabutr I, Axford JK, et al (2017) Wolbachia infections in Aedes aegypti differ markedly in their response to cyclical heat stress. Plos Pathogens 1-17

Shulse CD, Semlitsch RD, Trauth KM (2013) Mosquitofish dominate amphibian and invertebrate community development in experimental wetlands. J Appl Ecol 50:1244-1256

Silva HH, Da Silva IG (1999) Influência do período de quiescência dos ovos sobre o ciclo de vida de Aedes aegypti (Linnaeus, 1762) (Diptera, Culicidae) em condições de laboratório. Rev Soc Bras Med Trop 32: 349-355

Silva AS, Lobo KS, Da Silva JS, Vale CFS, Tadei WP, Pineiro VCS (2014) Influência dos fatores abióticos na efetividade de Bacillus thuringiensis var. israelensis (Berliner, 1911) para larvas de Aedes aegypti (Linnaeus, 1762). Rev Cubana Med Trop 66:174-190

SVS (2015) Boletim Epidemiológico Secretaria de Vigilância em SaúdeMinistério da Saúde. http://portalsaude.saude.gov.br/images/pdf/ 2016/janeiro/07/2015-svs-be-pncd-se48.pdf. Accessed 10 Nov 2016

SVS (2016) Brasil mantém situação de emergência por conta do Zika. http://portalsaude.saude.gov.br/index.php/o-ministerio/principal/ secretarias/svs/noticias-svs/26447-brasil-mantem-situacao-deemergencia-por-conta-do-zika. Accessed em 22 Nov 2016

Teixeira L, Ferreira A, Ashburner M (2008) The bacterial symbiont Wolbachia induces resistance to RNA viral infections in Drosophila melanogaster. PLoS Biol 6:2753-2763

Thangamani S, Huang J, Hart C, Guzman H, Tesh R (2016) Vertical transmission of Zika virus in Aedes aegypti mosquitoes. Am J Trop Med Hyg 95(5):1169-1173 
Tozan Y, Ratanawong P, Louis VR, Kittayapong P, Wilder-Smith A (2014) Use of insecticide-treated school uniforms for prevention of dengue in schoolchildren: a cost-effectiveness analysis. PLoS One 9:1-9. doi: 10.1371/journal.pone.0108017

Valença MA, Marteis LS, Steffler LM, Silva AM, Santos RLC (2013) Dynamics and characterization of Aedes aegypti (L.) (Diptera: Culicidae) key breeding sites. Neotrop Entomol 42:311-316

Valle D, Belinato TA, Martins AJ (2015) Controle químico de Aedes aegypti, resistência a inseticidas e alternativas. In: Valle D (ed) Dengue: teorias e práticas. Fiocruz, Rio de Janeiro, pp 93-126

Van Lenteren JC (2009) Critérios de seleção de inimigos naturais. In: Bueno VHP Controle biológico de pragas: produção massal e controle de qualidade. UFLA, Lavras, p 430

Varejão JBM, Biral Dos Santos C, Ricas Rezende H, Bevilacqua LC, Falqueto A (2005) Criadouros de Aedes (Stegomyia) aegypti (Linnaeus, 1762) em bromélias nativas na Cidade de Vitória, ES. Rev Soc Bras Med Trop 38:238-240

Walker T, Johnson PH, Moreira LA, Iturbe-Ormaetxe I, Frentiu FD, McMeniman CJ, Leong YS, Dong Y, Axford J, Kriesner P, Lloyd AL, Ritchie AS, O'Neill SL, Hoffmann AA (2011) The wMel Wolbachia strain blocks dengue and invades caged Aedes aegypti populations. Nature 476:450-453

Wallace H (2013) Mosquitos geneticamente modificados: preocupações atuais. HEINRICH BOLL, Rio de Janeiro, p 97

Wermelinger ED, Ferreira AP, De Carvalho RW, Da Silva AA, Benigno CV (2015) Aedes aegypti eggs oviposited on water surface collected from field ovitraps in Nova Iguaçu City, Brazil. Rev Soc Bras Med Trop 48: 770-772

Werren JH, Baldo L, Clark ME (2008) Wolbachia: master manipulators of invertebrate biology. Nat Rev Microbiol 6:741-751
WHO (2016) Organização Mundial da Saúde anuncia emergência de saúde pública de importância internacional. http://www.paho.org/ bra/index.php?option=com_content $\&$ view=article \&id=4991: organizacao-mundial-da-saude-declara-emergencia-de-saudepublica-de-importancia-internacional\&Itemid=816. Accessed 10 Nov 2016

Wilder-Smith A, Lover A, Kittayapong P, Burnham G (2011) Hypothesis: impregnated school uniforms reduce the incidence of dengue infections in school children. Med Hypotheses 76:861-862

Wilder-Smith A, Byass $P$, Olanratmanee $P$, Maskhao $P$, Sringernyuang $L$, Logan JG, Lindsay SW, Banks S, Gubler D, Louis VR, Tozan Y, Kittayapong $P$ (2012) The impact of insecticide-treated school uniforms on dengue infections in school-aged children: study protocol for a randomised controlled trial in Thailand. Trials 13:1-7

Wilkerson RC, Linton YM, Fonseca DM, Schultz TR, Price DC, Strickman DA (2015) Making mosquito taxonomy useful: a stable classification of tribe Aedini that balances utility with current knowledge of evolutionary relationships. PLoS One 10:1-26

Yeap HL, Mee P, Walker T, Weeks AR, O'Neill SL, Johnson P, Ritchie SA, Richardson KM, Doig C, Endersby NM, Hoffmann AA (2011) Dynamics of the "popcorn" Wolbachia infection in outbred Aedes aegypti informs prospects for mosquito vector control. Genetics 187:583-595

Zara ALSA, Maria dos Santos S, Fernandes-Oliveira ES, Carvalho RG, Giovanini EC (2016) Estratégias de controle do Aedes aegypti: uma revisão. Epidemiol e Serviços Saúde 25:391-403

Zeidler JD, Acosta POA, Barrêto PP, Cordeiro JDS (2008) Dengue virus in Aedes aegypti larvae and infestation dynamics in Roraima, Brazil. Rev Saude Pública 42:2-6 